\title{
Sheltering at Our Common Home
}

\author{
H.A.M.J. ten Have
}

Received: 18 April 2020 / Accepted: 3 August 2020

(C) Journal of Bioethical Inquiry Pty Ltd. 2020

\begin{abstract}
The current COVID-19 pandemic has reactivated ancient metaphors (especially military ones) but also initiated a new vocabulary: social distancing, lockdown, self-isolation, and sheltering in place. Terminology is not ethically neutral but reflects prevailing value systems. I will argue that there are two metaphorical vocabularies at work: an authoritarian one and a liberal one. Missing is an ecological vocabulary. It has been known for a long time that emerging infectious diseases are associated with the destruction of functioning ecosystems and biodiversity. Ebola and avian influenza viruses have been significant warnings. Obviously, this pandemic will not be the last one. As the planet is our common home, the major metaphor to explore is sheltering at this home.
\end{abstract}

Keywords Bioethics · Bio-invasion · Bio-preparedness Common home $\cdot$ Disasters $\cdot$ Ecology $\cdot$ Emerging infectious diseases $\cdot$ Pandemics $\cdot$ Sheltering at home Sheltering in place $\cdot$ Social distancing $\cdot$ War metaphor

\section{The Missing Perspective}

It has long been known that new pandemics will arrive, although it cannot be predicted when. Pandemics have been regarded as the most serious and likely global

H. ten Have $(\bowtie)$

Center for Healthcare Ethics, Duquesne University, 600 Forbes Avenue, Fisher Hall 300, Pittsburgh, PA 15282, USA

e-mail: tenhaveh@duq.edu catastrophic risk for the future (Global Priorities Project 2016). In 2003, it was estimated that since 1980 more than thirty-five new infectious diseases have emerged in humans; one every eight months (Smolinski et al. 2003). Since then the list has only grown (for example, the severe acute respiratory syndrome (SARS) coronavirus, swine influenza (H1N1 and other sub-types), the Middle East respiratory syndrome (MERS) coronavirus, Ebola virus disease (EVD), and the Zika flavivirus). Most of these outbreaks have been localized but the Human Immunodeficiency Virus (HIV), SARS, and avian influenza (H5N1 and other sub-types) should have been warnings that globalization can easily occur. Already in 2005, the WHO launched its Global Influenza Preparedness Plan, urging countries to make national bio-preparedness plans, and many countries did so (WHO 2005).

Furthermore, it has been known for some time that infectious diseases are promoted by environmental degradation as a result of biodiversity loss and climate change. Destruction of ecosystems is shrinking the wildlife habitat and increasing contacts between wildlife and human beings. It is estimated that zoonotic pathogens cause 60 per cent of emerging infectious diseases in humans (Jones et al. 2008; Daszak et al. 2004). The global threat of pandemics therefore does not emerge spontaneously as a natural event but is the product of human behaviour. It is a consequence of the human way of life and exploitation of the planet. Destruction of biodiversity creates the conditions for the emergence of new viral diseases (Quammen 2012). Although much is unclear, studies indicate that bats are the reservoir 
hosts for the novel coronavirus SARS-CoV-2 causing COVID-19, while pangolins might be possible hosts. Bats are very common mammals. They harbour around thirty different coronaviruses but in fact many more viruses, mostly unknown. Pangolins are the most frequently trafficked mammals, especially in China, used as a food source and for traditional medicine. They have been traded in the wet market in Wuhan where the infection emerged (Lam et al. 2020). Live animal markets, industrial livestock farming, trade in wild animals, and consumption of wildlife meat bring virus reservoirs in close contact with human beings. The only way to prevent future zoonotic diseases is to study the origin of pandemics. Instead of waiting for the next pandemic, epidemiological research should be expanded and stringent measures taken to prevent the "jumping" of viruses to humans. What is missing in the pandemic management responses so far is the ecological perspective that pandemics are related to the current economic global order which assumes a separation of humans and nature and regards nature as a resource to be exploited and commodified. The absence of an ecological perspective is highlighted in the images and words associated with COVID-19.

\section{Sheltering}

Sheltering in place is a notion from the Cold War. When there is an imminent nuclear threat, people should take refuge in a small, interior room, lock all windows and remain indoors, or move to special shelters. This usually takes a few hours, not days or weeks. (American Red Cross, 2003). The concept is also used for biological and chemical threats, as well as for extreme weather events. The basic idea is to wait until the worst is over; then go outside and resume normal activities. It assumes a specific view of disasters: they are sudden events with immediate but often localized impact such as tsunamis and tornadoes. Pandemics, however, are gradual disasters; they have slow impact, and move across the globe, potentially affecting everyone. The difference is important for the degree of preparedness. Since pandemics come in waves, not all regions and countries are simultaneously affected. This leaves time for preparation. It also means that sheltering will be extended for weeks perhaps months, not knowing how long it will provide security.
During a pandemic, sheltering at home seems a more acceptable term. It avoids connotations of mandatory quarantine or isolation. It is restricting freedom of movement but appeals to the responsibility of individuals. Contrary to shelter-in-place, sheltering at home is more lenient since it allows to go out for essential business and walking, keeping physical distance to other people. The notion of "home" generally has positive connotations. In distinction to "place" it is not a neutral location. It is where people live together in a space of intimacy and privacy, often regarded as a haven or refuge, a secure place to retreat and feel comfortable, a setting for caring relationships and conviviality (Mallet 2004). At home means more than residing in a specific place. Of course, not all homes are the same (e.g. nursing homes), not all homes are safe (e.g. domestic abuse), and not everybody has a home. Now that more than half of the world population is confined to their homes, philosopher Gaston Bachelard reminds us that beingat-home is more fundamental than activities such as working (Bachelard 2014). Nevertheless, the emphasis on sheltering and isolation reflects an individualistic perspective, assuming that people can easily withdraw from social interactions. In many cases, connections with environing conditions cannot be severed. For numerous people, especially in low- and middle-income settings, this is not an option. Also, poor people in affluent countries cannot shelter but have to expose themselves in order to subsist.

\section{The Vocabulary of the Pandemic}

The image of sheltering at home has become incorporated in popular discourse. Previously used in epidemiology, new words (e.g. self-isolation, social distancing, and lockdown) are now disseminated to advance images of control and containment. They visualize the spread of the virus, what we can do to avoid infection and to become aware of the effects of our behaviour. These images are associated with the war metaphor dominating current policies. The disease is regarded as a threat, the virus as enemy, leaders as commanders, and vaccines as new weapons.

Today's metaphor is associated with the older discourse of bio-invasion. Since the 1990s, many countries have developed policies to protect native biodiversity against invasive species. Non-native species are considered as aliens, enemies; we need to act to protect nature. 
The assumption is that nature and humans can be separated. Nature, and wildlife in particular, is regarded as a source of danger. However, bio-invasion is impossible to prevent. When mobility and interconnectedness are the hallmarks of globalization, bio-invasion is a global phenomenon par excellence since borders are irrelevant. The same applies to new, "emerging" viruses. Viral diseases have been with us since the beginning of humanity. They are now more easily disseminated through global traffic. The point is that these "new" viruses do not simply "emerge" as natural events. Their impact is the result of human activities.

The military metaphor is currently applied in most countries. The effect is reinforcement of boundaries. First, between inside and outside, enemies and friends. It blames people for "bringing in the virus." Second, individuals and social context are disconnected. Terminology is not ethically neutral but reflects prevailing value systems. When the virus moved across the world, some words (e.g. mandatory quarantines, containment zones, home confinement) were less often used in liberal societies. While the military metaphor is predominant, it is articulated in distinct policies: authoritarian and liberal ones. Both appeal to different normative frameworks which are often mixed in practical approaches. For example, "lockdown" and "quarantine" emphasize state measures beyond individual rights and freedoms. On the other hand, "self-isolation" appeals to individual responsibility. The term "social distancing" is typically neoliberal; it does not recognize the communal nature of many societies. What is at stake is physical (not social) distancing, while in many countries social connections and solidarity have grown. Emphasizing self-interest risks that other persons are seen as threats. Many countries, especially in the West, struggle with the balance between authoritarian and liberal policies. They are concerned with the protection of human rights and civil liberties. The discussion about the use of surveillance technologies and their impact on privacy is an example (Gostin, Friedman, and Wetter 2020). Since both authoritarian and liberal policies are animated by the military metaphor, they share the same urge to control. They reflect a system of governance that administers, fosters, and secures life by controlling the population and disciplining the individual. This application of "biopower" is closely linked to the ideology of neoliberalism in emphasizing internal regulation by autonomous subjects rather than external force and pressure (Foucault 2008; Kakuk 2017). Even in authoritarian countries, stringent policies will not succeed if they do not appeal to the responsibility of citizens. Emphasizing individual responsibility and empowerment, however, neglects the social, political, and economic dimensions of human life. It narrows bioethical discourse since it is difficult to conceptualize the significance of the context in which problems arise and to develop practices based on relationality and connectedness which are articulated in global bioethics with an ecological vocabulary.

\section{The Ecological Perspective}

Interconnectedness and interdependency articulate that humans cannot be separated from the surrounding world, not only society and culture but also the natural world of animals and plants. The starting point for bioethical discourse is therefore not individual autonomy but the broader context in which individuals are embedded. Self-isolation in this perspective is not merely protecting oneself but first of all protecting fellow citizens. The experience of togetherness is not restricted to humans but involves all forms of life, even viruses. Regarding humans as part of an interconnected web of life means moving from an anthropo-centric to biocentric approach with a relational concept of the self, dependent on biodiversity. This shift has been advocated by many environmental ethicists as well as in indigenous worldviews (Rolston 1988; Johnson 2020). The ecological perspective implies that the military language of the pandemic is distorting the human embeddedness in the natural world. Emphasizing the antagonism between humans and the virus as enemy, blames nature for diseases ignoring that diseases emerge due to environmental degradation as a result of human exploitation of biodiversity. It also disregards that microbes are inhabitants of our world; they have been and will be always there. Rather than eradication, cohabitation will be required. The military metaphor encourages the search for "magic bullets" that can attack and eliminate the virus. It also creates an atmosphere of secrecy, suspicion, and mistrust where facts, findings, and potential weapons are disputed and concealed.

Another consequence of the ecological perspective is a broader notion of health. Human health, animal health, and healthy ecosystems are linked. Human beings cannot be healthy when the planet is not healthy. The implication is that governance should be global. It should be focused on health as one, as a planetary 
concern. Applying the vision of One Health means monitoring and surveilling human connections with animals, specifically in the bioindustry. Another implication is that attention should not merely focus on morbidity and mortality but on prevention. Future pandemics will emerge if environmental destruction and loss of biodiversity are not addressed.

Global interconnectedness implies that citizens in one country will be exposed to diseases when they emerge in another country. The ecological perspective therefore stresses the need for solidarity. This is not just an ethical requirement, but a medical necessity. Closing borders, restricting travel, and concentrating on national interests had only a limited effect on the dissemination of COVID-19. Public health as a common good is essential for the well-being and survival of humanity. It will require cooperation and collective action, especially in the early stages of a pandemic disease when the caseload is still manageable and secondary prevention is possible. In an ecological perspective, vulnerability to infectious diseases is not confined to specific individuals, populations, or nations.

\section{Our Common Home}

While COVID-19 and its impact will be temporary, the effect of climate change is already there and will continue, requiring sustained action for a very long time (Guterres 2020). Both global threats are interpreted from a similar perspective: humans are not embedded in nature. The earth is a resource that can be commodified and exploited; it is not regarded as a living organism that creates and nourishes life (humans, animals, and microorganisms). The fact that many of us are now confined to our homes is hopefully an incentive to realize that we all share a common home. It demonstrates not merely interconnectedness of human beings manifested in society and culture but furthermore their embeddedness in the natural world. What affects the health of the planet will unquestionably deteriorate human health. Concepts such as "one health" and "planetary health" articulate the connection between healthcare and earthcare. They make clear that the focus of bioethics should go beyond individual health and that effective policies should be based on collective action (Ten Have 2019).

Given the interconnection between health and biodiversity, the notion of sheltering at our common home is most appropriate in the current circumstances. The earth is our home, as stated in the preamble of the Rio Declaration (United Nations 1992). Like all homes, this common home has dark sides, clearly noticeable today. But humans have no other dwelling place. Our actions can destroy this place but they can also turn it into a home where everyone feels safe and secure. Facing the COVID-19 pandemic is an opportunity to make ourselves at home in the world and to preserve our common home.

\section{References}

American Red Cross. 2003. Fact sheet on shelter-in-place. https://www.redcross.org/content/dam/redcross/atg/PDF s/Preparedness_Disaster_Recovery/Disaster Preparedness/Terrorism/shelterinplace.pdf. Accesse $\bar{d}$ June 12, 2020.

Bachelard, G. 2014. The poetics of space. New York: Penguin Books.

Daszak, P., G.M. Tabor, A.M. Kilpatrick, J. Epstein, and R. Plowright. 2004. Conservation medicine and a new agenda for emerging diseases. Annals of the New York Academy of Sciences 1026 (October): 1-11.

Foucault, M. 2008. The birth of biopolitics: Lectures at the Collège de France 1978-1979. London: Palgrave Macmillan.

Global Priorities Project. 2016. Global catastrophic risks. Stockholm: Global Challenges Foundation.

Gostin, L.O., E.A. Friedman, and S.A. Wetter. 2020. Responding to COVID-19: How to navigate a public health emergency legally and ethically. Hastings Center Report 50 (2): 1-5.

Guterres, A. 2020. Press Conference by Secretary-General Antonio Guterres at United Nations Headquarters, March 10. United Nations (Transcript SG/SM/20003). https://www.un.org/press/en/2020/sgsm20003.doc.htm. Accessed June 12, 2020.

Johnson, R. 2020. Indigenous jingle dress dancing goes "viral" on social media to help heal the world. CBC News, March 21. https://www.cbc.ca/news/indigenous/jingle-dress-dancehealing-covid-19-pandemic-1.5504903. Accessed July 16, 2020.

Jones, K.E., N.G. Patel, M.A. Levy, et al. 2008. Global trends in emerging infectious diseases. Nature 451(7181): 990-994.

Kakuk, P. (ed). 2017. Bioethics and biopolitics. Theories, applications and connections. Cham: Springer International Publishing.

Lam, T.T., M.H. Shum, H-C. Zhu, et al. 2020. Identifying SARSCoV-2 related coronaviruses in Malayan pangolins. Nature 583: 282-285. https://doi.org/10.1038/s41586-020-2169-0.

Mallet, S. 2004. Understanding home. A critical review of the literature. Sociological Review 52(1): 62-89.

Quammen, D. 2012. Spillover. Animal infections and the next human pandemic. New York/London: W.E. Norton and Company.

Rolston. H. 1988. Environmental ethics: Duties to and values in the natural world. Philadelphia: Temple University Press.

Smolinski, M.S., M.A. Hamburg, J. Lederberg, and Institute of Medicine, eds. 2003. Microbial threats to health: emergence, 
detection, and response. Washington DC: National Academies Press.

Ten Have, H.A.M.J. 2019. Wounded planet. How declining biodiversity endangers health and how bioethics can help. Baltimore: Johns Hopkins University Press.

United Nations. 1992. Rio Declaration on Environment and Development. United Nations General Assembly A/Conf.151/26 (Vol. I). https://www.un. org/en/development/des a/population /migration/generalassembly/docs/globalcompact/A CONF.151_26_Vol.I_Declaration.pdf. Accessed July 16, 2020 .
WHO. 2005. WHO global influenza preparedness plan. The role of WHO and recommendations for national measures before and during pandemics. Geneva, World Health Organization. https://www.who.int/csr/resources/publications /influenza/WHO_CDS_CSR_GIP_2005_5.pdf. Accessed June 12, 2020.

Publisher's note Springer Nature remains neutral with regard to jurisdictional claims in published maps and institutional affiliations. 